\title{
Performance Evaluation of Sunflower (Helianthus annus L.) under Cluster Front Line Demonstration Programme in Samastipur District, Bihar, India
}

\author{
Sanjay Kumar*, R. K. Tiwari, Shailesh Kumar, Ranjan Kumar, Sanchita Ghosh, \\ Bharati Upadhaya, Nisha Rani and Vidyapati Choudhary
}

\author{
Krishi Vigyan Kendra, Birauli, Samastipur-848113, Dr. Rajendra Prasad Central \\ Agricultural University, Pusa, Samastipur, Bihar, India
}

*Corresponding author

\section{A B S T R A C T}

Keywords

Sunflower, CFLD, yield, $\mathrm{B}: \mathrm{C}$ ratio, technology index

\section{Article Info}

Accepted: 05April 2020 Available Online: 10 May 2020
The Cluster Front Line Demonstration (CFLD) programme on Sunflower was carried out during 2017-18 in operational area of Krishi Vigyan Kendra, Samastipur. The plots were selected from different villages/clusters (each of 0.2$0.4 \mathrm{ha})$ from the district. The variety 'KBSH-44' was used in both the demonstrated plots and farmers field. Fertilizer, herbicides, irrigation application and plant protection measures were taken as per improved package of practices. During the CFLD programme, it was found that the seed yield of sunflower was $12.06 \mathrm{q} / \mathrm{ha}$ in demonstration field as compared to seed obtained from farmers field $(9.78 \mathrm{q} / \mathrm{ha})$. The technology gap was found to be $5.94 \mathrm{q} / \mathrm{ha}$. The $2.28 \mathrm{q} / \mathrm{ha}$ extension gap was found in that year. The technology index was $33.0 \%$. Higher gross returns (Rs 42210/ha), net return (Rs. 18370/ha and benefit-cost ratio of 1.77 were found in demonstrated field as compared to benefit-cost ratio of 1.42 in case of local check. The significant yield is attributed due to introduction of new variety in cluster mode which facilitated better crop management.

\section{Introduction}

India occupies a premium position in global oilseed scenario, accounting for $21 \%$ oilseed cultivation area and $15 \%$ of oilseed production. Edible oils and oil meals have a pivotal role in addressing malnutrition and caloric nutrition of human and animals population (Malik et al., 2014) Sunflower holds promising position among edible oilseed crops due to its premium oil quality and it fits well in cropping systems due to its sub duration, higher yield potential and wide adoptability to different agro-climatic regions. It is widely cultivated in Karnataka, Maharashtra, Tamil Nadu and Andhra Pradesh. In Bihar, it is cultivated in 0.31 million ha with a production of 0.22 million 
tones and productivity of $1402 \mathrm{~kg} / \mathrm{ha}$ (Nayak et al., 2013). It is an exhaustive crops and responds well to the fertilizers. The crop gain good popularity among the growers because of its attractive price and demand for its oils. It is an energy rich oilseed crop, so nutrient management play important role that greatly affect the growth and yield of sunflower.

In order to promote oilseed cultivation, the Government of India has devised a programme in cluster mode under National Food Security Mission through KVKs. The main objective of CFLD is to demonstrate production technology and its management practices on farmer's field under different farming situations. These demonstrations are carried out under the supervision of agricultural scientists and feedbacks from the different farmers have to be generated on the demonstrated technology. Keeping the importance of CFLD the KVK, Samastipur conducted demonstrations on sunflower at farmer's field. The present study has been undertaken to increase the per capita availability of oilseed and popularization of new production technology amongst the farming community by promoting sunflower crop production employing improved practices.

\section{Materials and Methods}

The study was carried out in operational area of Krishi Vigyan Kendra, Samastipur during 2017-18. The crop was sown in the plots after the harvest of potato/rapeseed-mustard selected from different villages/clusters (each of 0.2-0.4 ha) from the district (Table-1). The total area of 10 ha has been allotted to KVK, Samastipur by ICAR-ATARI, Patna (Zone IV). The critical inputs were supplied to the farmers by the KVK while other inputs like balanced fertilizers, additional agrochemicals, herbicides, irrigation facility were managed by farmers himself as per recommendation of scientists of KVK. The sunflower variety 'KBSH-44' was sown during second fortnight of February to first fortnight of March adopting line sowing method using seed drill. A spacing of $60 \times 30$ $\mathrm{cm}$ was maintained with a seed rate of 5 $\mathrm{kg} / \mathrm{ha}$. Before sowing, seed was soaked in water for 16 hours and shade dried for 6 hours and dressed with Thiram @ $2.5 \mathrm{~g} / \mathrm{kg}$ of seed.

The half dose of nitrogen and full dose of phosphorous, potassium and sulphur fertilizer was applied as basal at the time of sowing and half of the nitrogenous fertilizer was applied in two splits as top-dressing, after first and second irrigation, respectively. Recommended package of practices were followed for raising the crop along with need based weed control and plant protection measures.

Earlier the farmers grow this crop by their own methods through seed broadcasting etc. kept as local which is considered as standard check during this trial. All the farmers were trained for improved package of practices beforehand through training programme. Materials for the present study with respect to CFLD and farmers practices are given in Table-2.

In case of local check plots, existing practices being used by farmers were followed. Regular visit by the KVK scientists to demonstration field were made to guide the farmers. These visits also helped to collect feedback from different farmers for further improvement in research and extension programme.

Field days, awareness camp and group meeting were also organized at the demonstration plots to provide the opportunities for vicinity farmers to witness the benefits of these demonstrated technologies. The improved technology includes quality seed, seed treatment and maintenance of optimum plant population etc. 
Recommended weed control measure and irrigation were applied according to the requirement of the crop. The crop was harvested at perfect maturity stage with suitable method.

Desired yield data were collected through field observations. Gross return was calculated by multiplying yield into prevalent local market price of the crop obtain by the farmers. For estimating input cost, the sum of expenditure on land preparation, planting method, fertilizer, insecticide, fungicide, herbicide, irrigation cost, labour wages, harvesting cost etc were calculated from each demonstration. Further, net return and benefitcost ratio were calculated from these data. To estimate the technology gap, extension gap and technology index formula devised by Samui et al., (2000) have been used as given below:

Technology gap $=$ Potential yield Demonstration yield

Extension gap $=$ Demonstration yield Farmers yield

Technology index = Technology gap/Potential yield x 100.

\section{Results and Discussion}

The result of 40 demonstrations conducted during summer 2017-18 at farmers' field in Samastipur district has been presented in Table-3 as per the prescribed proforma provided by ICAR-Agricultural Technology Application Research Institute (ATARI), Patna (Zone-IV). Farmers adopted the improved technology practices for the cultivation and the crop was supervised by the scientists of KVK, Samastipur as per the area allotted by ATARI, Patna. The data revealed that the CFLD reflects good impact over the farming communities.
A comparison of productivity levels between local check and demonstrated variety and practices are shown in Table-3. The seed yield of sunflower was $12.06 \mathrm{q} / \mathrm{ha}$ in demonstration field as compared to seed obtained from farmers field $(9.78 \mathrm{q} / \mathrm{ha})$. Demonstration plot resulted in $18.90 \%$ higher seed yield from local check. Similar findings have also been observed by Jain (2016) and Kumar et al., (2018) where results from demonstrations plots observed to be higher in summer green gram and lentil crop.

The major differences were observed between demonstration package and farmers' practices are introduction of seed treatment, method and time of sowing, fertilizer doses and method of its application and plant protection measures. It is evident from the results that the yield of demonstration was found better than the local check (farmer's practice) under the similar environmental conditions.

Farmers were motivated by results of demonstration and agro-technologies applied in the cluster front line demonstration and they would adopt these all new technologies in their fields. These findings are in corroboration with the finding of Kushwah et al., (2016) and Singh et al., (2018).

The technology gap is the gap between demonstration yield and potential yield and it was $5.94 \mathrm{q} / \mathrm{ha}$. The observed technology gap as presented in Table- 3 is due to various constraints such as soil fertility, availability of low soil moisture content, sowing time and climatic hazards etc. This indicates that a gap existed between technology evolved and technology adoption at farmer's field. Hence, to reduce the yield gap, location specific recommendations for varieties and timely sowing appears to be necessary. The $2.28 \mathrm{q} / \mathrm{ha}$ extension gap was found in that season. 
Table.1 Details of farmers and cluster in different blocks of Samastipur district under CFLD programme

\begin{tabular}{|c|c|c|c|c|c|}
\hline \multirow[t]{3}{*}{ Year } & \multirow[t]{3}{*}{ No of farmers } & \multicolumn{4}{|c|}{ Name of Blocks \& Villages of Samastipur District } \\
\hline & & \multirow{2}{*}{$\begin{array}{c}\text { Pusa } \\
\text { Gangapur }\end{array}$} & \multicolumn{3}{|c|}{ Hasanpur } \\
\hline & & & Devra & Ghosdaha & Sapari \\
\hline 2017-18 & 40 & $09(1)$ & $19(01)$ & $02(01)$ & $10(01)$ \\
\hline
\end{tabular}

Parenthesis indicates number of cluster in each village

Table.2 Comparison of cultural practices adopted by farmers and CFLD

\begin{tabular}{|c|c|c|}
\hline Cultural operations & Prevailing Practices & CFLD employing improved cultivation practices \\
\hline Use of seed & Use of local seed & KBSH-44 \\
\hline Seed quality & Small non-graded seed & Bold graded seed \\
\hline Seed treatments & - & Water soaking followed by Thiram treatment \\
\hline Method of sowing & Broadcasting & Line sowing by seed drill \\
\hline Fertilizer application & - & $80: 90: 40 \mathrm{NPK}+30 \mathrm{~S} \mathrm{~kg} / \mathrm{ha}$ \\
\hline Control measures & $\begin{array}{l}\text { Single spray of pesticide when severe } \\
\text { problem occurs }\end{array}$ & $\begin{array}{l}\text { Two spray of insecticides to control of insects and application of micronutrients for more } \\
\text { branches and healthy plants as well as seeds }\end{array}$ \\
\hline
\end{tabular}

Table.3 Yield, technology gap, extension gap and technology index of sunflower in Samastipur

\begin{tabular}{|c|c|c|c|c|c|c|c|c|c|c|c|c|c|c|}
\hline \multirow[t]{3}{*}{ Year } & \multirow{3}{*}{$\begin{array}{l}\text { Name of } \\
\text { variety }\end{array}$} & \multirow{3}{*}{$\begin{array}{c}\text { No of } \\
\text { demonstration }\end{array}$} & \multicolumn{7}{|c|}{ Yield (q/ha) } & \multirow{3}{*}{$\begin{array}{c}\text { Yield } \\
\text { increase } \\
(\%)\end{array}$} & \multirow{3}{*}{$\begin{array}{c}\% \\
\text { increase } \\
\text { over } \\
\text { check }\end{array}$} & \multirow{3}{*}{$\begin{array}{l}\text { Technology } \\
\text { gap (q/ha) }\end{array}$} & \multirow{3}{*}{$\begin{array}{l}\text { Extension } \\
\text { gap (q/ha) }\end{array}$} & \multirow{3}{*}{$\begin{array}{l}\text { Technology } \\
\text { index }(\%)\end{array}$} \\
\hline & & & Potential & & onstra & & & Check & & & & & & \\
\hline & & & & Max. & Min. & Av. & Max. & Min. & Av. & & & & & \\
\hline 2017-18 & KBSH-44 & 40 & 18 & 13.68 & 10.44 & 12.06 & 10.03 & 09.53 & 09.78 & 18.90 & 23.31 & 5.94 & 2.28 & 33.00 \\
\hline
\end{tabular}

Table.4 Gross cost, gross return, net return and B: C ratio of sunflower cultivation in Samastipur

\begin{tabular}{|c|c|c|c|c|c|c|c|c|}
\hline \multirow[t]{3}{*}{ Year } & \multicolumn{8}{|c|}{ Expenditure and return } \\
\hline & \multicolumn{4}{|c|}{ Check plots } & \multicolumn{4}{|c|}{ Demonstration plots } \\
\hline & Gross cost (Rs/ha) & $\begin{array}{c}\text { Gross Return } \\
\text { (Rs/ha) }\end{array}$ & $\begin{array}{c}\text { Net return } \\
\text { (Rs/ha) }\end{array}$ & B:C ratio & $\begin{array}{c}\text { Gross cost } \\
\text { (Rs/ha) }\end{array}$ & $\begin{array}{c}\text { Gross Return } \\
\text { (Rs/ha) }\end{array}$ & $\begin{array}{c}\text { Net return } \\
\text { (Rs/ha) }\end{array}$ & B:C ratio \\
\hline 2017-18 & 24130 & 34230 & 10100 & 1.42 & 23840 & 42210 & 18370 & 1.77 \\
\hline
\end{tabular}

Sale rate of sunflower during 2017-18 : Rs. 3500/q 
There is a need to decrease this wider extension gap through latest techniques. The findings are similar to the findings of Patil et al., (2015) and Sandhu and Dhaliwal (2016). The technology index showed the feasibility of evolved technology at farmer's field. Lower technology values indicated that the feasibility of variety among the farmers is more. The technology index was 33\%. This finding is in corroboration with the findings of Kushwah et al., (2016) and Kumar et al., (2018). The economics of sunflower production under CFLD have been presented in Table-4.

Economic analysis of the yield performance revealed that CFLD recorded higher gross return (Rs 42210/ha) and net return (Rs. 18370/ha) with higher benefit-cost ratio 1.77 compared to 1.42 in case of local check. The sale rate of sunflower in local market during 2017-18was@ Rs.35/kg.

The higher benefit cost ratio in demonstrated plot is due to of higher yield obtained under improved technologies compared to farmer's practices during the experimental year. Similar results were corroborated with Kumar et al., (2018). It is concluded from the study that through CFLD of recommended improved technologies the yield of sunflower can be increased to its potential yield in Samastipur district. This will substantially increase the income as well as livelihood of the farming communities.

\section{References}

Jain, L. K. 2016. Impact assessment of front line demonstrations on green gram in Barmer district of Western Rajasthan. Journal of Food Legumes, 29 (3 \& 4) : 249-252.

Kumar, S., Tiwari, R.K., Ashthana, R.K. and Kumar, Shailesh, 2018. Evaluation of different dultivars of lentil under cluster front line demonstration programme in Samastipur District, Bihar. Journal of Community Mobilization and Sustainable Development. 13 (2): 271274.

Kushwah, S., Kumar, S. and Singh, S.R.K. 2016. Adoption of improved late sown mustard cultivation practices - A case study in Bihar. Journal of Community Mobilization and Sustainable Development. 11 (1): 19-23.

Malik, M.A., Wani, Mushtaq, A. and Wani, J.A. 2014. Effect of P, FYM and PSB on Macronutrient concentration and upkate by Sunflower. Journal of Indian Society of Soil Science. 62 (3) : 269273.

Nayak, A., Gracoy, C.P., Nagasree, N. and Girisha, K. 2013. Online www.krishisewa.com/articles/miscellan eous/284-sunflower.html

Patil, L.M., Modi, D.J., Vasava, H.M. and Gomkale, S.R. 2015. Evaluation of front line demonstration programe on green gram variety Meha (IPM-99-125) in Bharuch district of Gujarat. Journal of Agriculture and Veterinary Science, 8 (9) : 1-3

Singh, K.H, Meena, K.C., Meena, B.L. and Meena, Ram Kishan. 2018. Effect of Front Line Demonstration on Sunflower in Eastern Region of Rajasthan. International Journal of Microbiology Research. 10 (3): 1024-1026.

Samui, S.K., Maitra, S., Roy, D.K., Mondal, A.K. and Saha, D. 2000. Evaluation of front line demonstration programme on groundnut (Arachis hypogea L.). Journal of Indian Society of Coastal Agriculture Research, 18 (2) : 180-183.

Sandhu, B.S. and Dhaliwal, N.S. 2016. Evaluation of front line demonstration programme on summer moong in south Western Punjab. Journal of Food Legumes, 29 (3 \& 4) : 245-248. 
How to cite this article:

Sanjay Kumar, R. K. Tiwari, Shailesh Kumar, Ranjan Kumar, Sanchita Ghosh, Bharati Upadhaya, Nisha Rani and Vidyapati Choudhary. 2020. Performance Evaluation of Sunflower (Helianthus annus L.) under Cluster Front Line Demonstration Programme in Samastipur District, Bihar, India. Int.J.Curr.Microbiol.App.Sci. 9(05): 310-315.

doi: https://doi.org/10.20546/ijcmas.2020.905.033 